\title{
mssaico
}

\section{A imaginação museal:} apresentação

Myrian Sepúlveda dos Santos ${ }^{1}$

\section{Obra:}

A imaginação museal: museu, memória e poder em Gustavo Barroso, Gilberto Freyre e Darcy Ribeiro.

Mario Chagas

Rio de Janeiro: Ibram/Garamond, 2009.

\footnotetext{
${ }^{1}$ PPCIS / UERJ, Rio de Janeiro (RJ).
} 
Aos que vierem depois de nós

Bertolt Brecht ${ }^{2}$

Realmente, vivemos muito sombrios!

A inocência é loucura. Uma fronte sem rugas denota insensibilidade. Aquele que ri ainda não recebeu a terrível notícia que está para chegar.

(...)

Também gostaria de ser um sábio. Os livros antigos nos falam da sabedoria: é quedar-se afastado das lutas do mundo e, sem temores, deixar correr o breve tempo. Mas evitar a violência, retribuir o mal com o bem, não satisfazer os desejos, antes esquecê-los é o que chamam sabedoria. E eu não posso fazê-lo. Realmente, vivemos tempos sombrios.

Aceitei a difícil tarefa de apresentar ao leitor o trabalho de Mario Chagas, autor que não só se auto-define pela poesia, como é atravessado por ela. É, portanto, poeticamente que Mario desfia sua narrativa, em desafio. Eu o conheci como pertencendo ao mundo dos museus, em uma época em que estes ainda se apresentavam para mim como instituições que retiravam os objetos da vida e os mumificavam entre suas paredes, a serviço de narrativas dominantes, freqüentemente opressoras. Frente ao poder institucional de aprisionamento da história, muitas vezes a solução surgia aliada a desejos de destruição. Mario, entretanto, estava em companhia daqueles que me mostraram os museus como arenas públicas, em toda sua possibilidade produtiva e criadora.

O museu, nas mãos do poeta, transformando-se em palco da vida, me faz lembrar a criação do teatro épico por Brecht. Também ele revolucionou a dramaturgia cênica, em voga no período em que viveu, ao rejeitar a representação da mesmice, das hierarquias formadas, da sociedade que a engendrava. No lugar da passividade, propôs a crítica à repetição por meio da poesia. Para o compositor alemão, a poesia não se distancia da política, da intervenção na vida cotidiana, das possibilidades de transformação que lhe são dadas. Ela critica o saber que procura distanciar-se da vida, e, contrariamente, para ela retorna seu

2 Tradução de Manuel Bandeira. Caderno "Mais!", jornal Folha de São Paulo - São Paulo (SP), edição de 07/07/2002. 
olhar. Além disso, faz parte da atividade, que é a um só tempo poética e crítica, o desfazer das ilusões. O cenário do teatro para Brecht não pode iludir o espectador, ele precisa se desnudar e mostrar-se enquanto montagem; as cortinas precisam ser rasgadas de modo a que os refletores, maquinários e estruturas fiquem aparentes. O questionamento do mundo é dado à medida que se questiona o autor do questionamento. Somente desta forma democratiza-se o diálogo; rompe-se com o poder daqueles que detêm o controle sobre as regras que determinam os jogos de linguagem.

A atualidade de Brecht, que após 50 anos de sua morte continua a ser homenageado e relembrado, repousa justamente no caráter inquieto de sua obra, que foge da contemplação e abraça, ainda que em tempos sombrios, a possibilidade de mudança. No caso de Mario, observamos a mesma indisciplina e criatividade de pensamento, pois sua poesia é capaz de iluminar o que muitas vezes se apresenta como fúnebre e intocável. A reinvenção dos museus, respeitando continuidades e descontinuidades, é o que o leitor poderá perceber ao longo da leitura desse trabalho.

O objetivo central da obra é compreender a imaginação museal de Gustavo Barroso, Gilberto Freyre e Darcy Ribeiro. Mario nos mostra que estes pensadores, capazes de oferecer à nação poderosas interpretações sobre seus pertencimentos e distanciamentos da mesma, aliaram suas narrativas às tarefas dos museólogos. Para o autor, a coleta de um acervo no interior de uma instituição, seja a de um catador de pregos, seja a de ideólogos da nação, representa a reinvenção do objeto num campo aberto de possibilidades.

Nas palavras do próprio autor:

Desses acervos, no entanto, não foi alijada a possibilidade de serem provocadores de experiências afetivas e cognitivas e menos ainda a de serem mediadores de narrativas biográficas, etnográficas, regionalistas e nacionalistas. A musealização de alguns 'inutensílios' não deve ser lida como mera ação acumulativa.

É a partir dessa premissa que este livro, resultado de uma pesquisa de doutorado, nos permite revisitar os museus. Os museus são vistos através de narrativas e práticas sociais em que imaginação poética e práxis política se entrelaçam. Três pensadores, todos consagrados pelas Ciências Sociais, observaram, descreveram e atuaram sobre seu mundo. Os três intelectuais contribuíram para a constituição de coleções que devem ser lidas como parte de suas narrativas e como a intervenção de cada um deles no cenário da nação. Eles criaram imaginários próprios para a nação e a eles associaram os museus ideais.

Gustavo Barroso foi o grande defensor da criação de um discurso histórico e patriótico para a nação. Foi ele o fundador do Museu Histórico Nacional e o grande 
responsável pela institucionalização da museologia no Brasil, através do Curso de Museus. Gilberto Freyre, responsável pelo resgate de padrões culturais inerentes às relações entre Casa Grande e Senzala, foi o idealizador e fundador do Museu de Antropologia, do Instituto Joaquim Nabuco de Pesquisas Sociais. Mais tarde, este museu - associado ao Museu do Açúcar e ao Museu de Arte Popular - deu origem ao Museu do Homem do Nordeste. Em Darcy Ribeiro, a antropologia inicialmente se colocou a serviço da causa indígena. Com o passar do tempo, os primeiros estudos sobre o impacto da civilização sobre os grupos indígenas brasileiros desdobraram-se em análises e políticas intervencionistas mais gerais sobre desigualdades sociais na América Latina. Darcy Ribeiro foi vice-governador do estado do Rio de Janeiro, em 1982; e, Senador, em 1990. Exerceu inegável influência na criação do Museu do Índio, no Rio de Janeiro, instituição que se voltou contra a opressão de grupos indígenas. Colaborou ainda na criação do Memorial da América Latina, construção modernista com traçado de Oscar Niemeyer, localizado em São Paulo. Em suma, três autores, três sentenças; em cada um deles uma associação particular entre nação e patrimônio. Em Gustavo Barroso, Mario destacou a associação entre história, nação e museu; em Gilberto Freyre, tradição, regionalismo e museu; e, em Darcy Ribeiro, etnia, cultura e museu.

Gustavo Barroso, Gilberto Freyre e Darcy Ribeiro foram responsáveis pela preservação de coleções e pela criação de instituições que desenvolveram perspectivas e práticas bastante distintas. A valorização e institucionalização de determinados acervos, sejam eles biográficos, etnográficos, históricos ou artísticos, os eleva à categoria de patrimônio cultural, ainda que eles façam parte de narrativas contraditórias entre si.

Ao colocar as coleções que são apresentadas em diálogo, Mario ilumina o que é inerente a todas elas, seu caráter mediador. O museu aparece, portanto, em sua dimensão dual: instituição necessária ao poder e espaço de negociação entre o poder estabelecido e as inúmeras vozes que podem ser ouvidas.

Mas, como fica claro ao longo do texto, os museus não se limitam à função de mostrar contradições; sua natureza é a coleção. À semelhança do conjunto de objetos constituído pelo 'Catador' de pregos, a coleção - por mais inútil que pareça - garante ao colecionador a soberania do 'Ser' sobre o 'Ter'. E, justamente, ao desnudar a tarefa do colecionador, que Mario transforma a tarefa do profissional do museu, pois ele dá ao espectador a possibilidade de tomar decisões. Todos nós somos colecionadores e podemos reagir e interferir na formação de coleções.

A função dos museus continua a ser ambígua; eles são locais privilegiados para a representação dos discursos de valor em uma sociedade e arena pública. Para alguns, uma bomba jogada em museus e monumentos ainda representa um favor à humanidade; para outros, ao contrário, eles representam espaços de interpretação e construção social. Mario foge da dualidade, das malhas da ambigüidade, e nos apresenta uma saída; seu desejo é o de 
resgatar a natureza desse espaço, e, com isso ser capaz de democratizar as regras do jogo; sua poesia procura diálogo com uma plateia que se constitua de forma ativa, pensante e questionadora, ou seja, que domine a ação de colecionar (e descolecionar, eu gostaria de dizer) e seja capaz de lhe responder o desafio proposto. 